\title{
PLÁNY VYŠEHRADU V NÁRODNÍ KNIHOVNĚ V PǍ̌ÍŽI
}

\author{
BOŘIVOJ NECHVÁTAL
}

\begin{abstract}
Abstrakt: V obdobi války o tzv. dědictvi habsburské (1741-1748) byly Praha a Vyšehrad obsazeny francouzským vojskem (1741-1742). Vojenský inženýr a architekt du Portal, který se účastnil tohoto vojenského taženi do Čech, nakreslil při ném plány Chebu, Boru u Tachova, Plzné, Berouna a Prahy, ale především Vyšehradu. Byly zde prováděny rozsáhlé práce na vylepšení obranného systému pod vedením generála ing. Berdiquiera. Francouzům šlo především o obranu barokni pevnosti proti městu. Celý obvod hradby nad Podvyšehradím od staré gotické karlovské zdi přes Nuselské údoli až po bastion sv. Leopolda, včetně nového ravelinu, zabezpečili krytou cestou s dvěma řadami palisád. K ovládání řky pod Vyšehradem osadili Francouzi palisády podél celého pobřeží. Atlas ing. du Portala obsahuje plány Vyšehradu, jak vypadal při př́chodu francouzského vojska, plány opevněni a ubytováni vojska, plán opevnéni proti Novému Městu a proti Vltavě, projekt př́stavby citadely a kasáren (pro 1200 mužů), plány di̊stojnického pavilonu, muničních skladišt' a dalšich objektü.

Soubor atlasu plánů ing. du Portala (celkem 30 plánů) jednoznačně svědči o tom, stejně jako ikonografické prameny ze 17. a 18. století, že v úseku plošiny hradiště na jižni straně v oblasti kanovnických zahrad a na severní straně v oblasti Karlachových sadủ nedošlo k poškození terénu pri fortifikačních pracích. Stratigrafie jsou zde zachovány v pưvodním stavu, jak svědči kromě jiného i nález trikonchy, byzantské architektury datované do konce 10. století do období Boleslava II. (972-999), a dávají tím možnost archeologického výzkumu na desetiletí.
\end{abstract}

Klíčová slova: obranný systém - palisády - bastion - ravelin - Vyšehrad.

\section{Plans of Vyšehrad in the Paris National Library}

Abstract: During the War of the Austrian Succession (1741-1748), Prague and Vyšehrad were occupied by the French army (1741-1742). The military engineer and architect Du Portal who took part in this military campaign in the Czech lands drew in its course the plans of Cheb, Bor u Tachova, Plzeñ, Beroun and Prague, and especially Vyšehrad. Extensive work on the improvement of the defence system was then in progress in Vyšehrad, supervised by General Berdiquier. The main objective was the defence of the baroque fortress against the town. The whole perimeter of the town wall above the Podvyšehradi area, from the old Gothic Karlov walls through the Nuselské údoli valley to the Bastion of St. Leopold, including a new ravelin, was reinforced with a double sheltered route with two rows of palisades. To control the river below Vyšehrad, the French installed palisades along the whole river bank. Du Portal's atlas contains plans of Vyšehrad, the way it looked upon the arrival of the French army, plans of the fortification and the army's accommodation, the plan of the fortification against the New Town and the Vltava, the plan for the construction of a citadel and barracks (for 1,200 men), plans for the officers' pavilion, ammunition and gun powder storehouses and other buildings.

The set of Du Portal's plans (30 in total) clearly shows, along with iconographic sources from the 17th and 18th centuries, that there was no damage to the terrain on the plateau of the fortress on the south side, in the area of canonry gardens, and on the north side, in the Karlachovy sady area, during the fortification work. Stratigraphies are preserved in their original state as evidenced, for example, by the excavation of triconcha, an element of Byzantine architecture dated to the late 10th century and the reign of Boleslav II (972-999), thus opening the possibilities of archaeological research for several decades.

Key words: defence system - palisades - bastion - ravelin - Vyšehrad.

První plány a práce na zlepšení vyšehradských hradeb, které byly budovány ještě ve 14. století za Karla IV., se objevily již záhy po bitvě na Bílé hoře. Již v roce 1621 měly být zahájeny blíže neurčené práce za účasti ing. Ferdinanda hr. z Nargolu a vedení Hanse Pohla z Punsonu. Určitým impulsem k tomu snad mohlo být nařízení Ferdinanda II. z roku 1622 - „všechno potřebné, aby se provedlo nejen $k$ hradu pražského, ale $i$ města hory Vyšehradu opraveni a znovu zř́zeni"“ (NA Praha, PSM, P 125/43). Základní podklady pro císaře vypracovala pochozí komise, kterou tvořili stavební písař Pražského hradu Jiljí Fuchs, malostranský písař Jakub Hýbl a primas s konšely města Vyšehradu. Již před Vánocemi roku 1622 prošla komise Vyšehrad a pozemky s vinicemi kolem hradeb a konstatovala destrukce kostelů, hradních a kapitulních budov. Došla 
k názoru, že je třeba nejprve vybudovat město a teprve potom opravovat šance. Doporučila císaři pro nejbližší dobu chránit staré hradební zdi baštami, které měly být budovány podle tehdy obvyklého způsobu vlašského z hlíny a dřeva, opatřené palisádami. Z následujícího roku 1623 je další císařské nařízení, které žádá vybudování pevné pražské citadely a nutné zpevnění hradebních zdí, př́ípadně vybudování nových. $Z$ nově probíhajících kontribucí byla určena částka 5000 kop míšeňských na opravu hradeb. Stavební práce provedl následně Hans Pohl z Punsonu. Práce spočívaly především v uvolnění a zpřístupnění starých zdí. Bylo ubouráno 20 objektů, které přiléhaly těsně $\mathrm{k}$ hradbám, a současně také východní část dvoulodního kostelíka Stětí sv. Jana Křtitele v blízkosti rotundy sv. Martina. Jeho polygonální závěr přesahoval původně přes vnější hradební líc. Již na základě doporučení komise z roku 1622 je možno předpokládat celkové zesílení hradby vnějšími bastionovými násypy tam, kde terén neposkytoval přirozenou ochranu. Bylo to především na planině před karlovskou bránou Špičkou. Představu těchto úprav poskytují především mladší Merianovy mědirytiny podle kreseb Karla Škréty, zobrazující dobývání Nového Města pražského Švédy roku 1648. Sypané bastiony měly zpevněné šikmé líce, široké prredprsně, vnější příkop před nimi byl lemován hřebenem kủlové palisády. Postup obnovy pražských fortifikací byl zřejmě pomalý a liknavý, takže z roku 1625 je další urgence císaře. Z nařízení českého místodržícího z roku 1631 je patrno, že Vyšehrad je používán jako velké skladiště střelného prachu a dalšího vojenského materiálu (Nechvátal 2012, 254-256).

Saský vpád do Prahy v roce 1631 vedl k podstatnému zrychlení prací, pro změnu pod dohledem okupačních úředníků. Počet obyvatelstva se na Vyšehradě v polovině 30. let 17. století pohyboval kolem 200 osob. Představoval asi třetinu počtu před třicetiletou válkou. Úbytek obyvatel byl způsoben nejen válečnými událostmi a demolicí budov při rekonstrukci starých, ještě gotických hradeb, ale zejména protireformační politikou vyšehradské kapituly. V roce 1639 dělostřelecká palba Švédů na Nové Město z postavení na Pankráci poškodila zčásti i Vyšehrad. Po odchodu Švédů dochází nadále k dalším opravám staré karlovské hradby, ale také k opravě a výstavbě sypaných bastionů. V roce 1639 velitel císařských vojsk hrabě Gallas výslovně nařídil, aby byly opravovány vyšehradské zdi a brána. V roce 1642 upozorňoval vyšehradský děkan Václav Plocar z Růžové na poškozené a poničené hradby pod vyšehradskou skalou u Botiče, kterými by se mohl nepř́tel dostat do města.

Skutečně největší pohromu pro vyšehradské hradby přinesl samý konec třicetileté války při druhém vpádu Švédů do Prahy v roce 1648. V tomto období byla na Vyšehradě umístěna posádka, která měla zabránit skupině švédských vojsk na Smíchově spojení s hlavní skupinou, na druhé straně města. V této době se k Praze blížila třetí švédská armáda pod vedením falckraběte Karla Gustava a na blízkém Pankráci byly jízdní oddíly generála Wittenberka. Vedení švédských vojsk sice neuvažovalo o dobývání Vyšehradu, ale jejich oddíly začaly ze svého postavení u kostela sv. Pankráce soustředěně ničit a bombardovat Vyšehrad.

Po skončení třicetileté války byly znovu obnoveny plány na přestavbu Vyšehradu. Jejich počátek je spatřován ve zprávě, kterou napsal italský generál Raimund Montecuculi. V memorandu zaslaném do Vídně polnímu maršálkovi Jindřichu hr. Šlikovi doporučuje v Čechách postavit sedm pevností. Mezi nimi jmenuje především Prahu jako „hlavni město a srdce zeměc. Zde měly být vybudovány dvě citadely - jedna na Strahově nebo na Hradě a druhá na Vyšehradě.

Autorem generálního plánu na vybudování pražské pevnosti se stal jeho pražský spolubojovník proti Švédům plukovník Inocentio de Conti. Uplatnil zde své zkušenosti vojáka, který bojoval v prvních liniích obleženého města. Vycházel ze starších nerealizovaných plánů, např. Alexandra Barriho a hr. Rudolfa Colloreda ze 30. let 17. století.

Tehdejší celkový stav pražské fortifikace před návrhem hr. Colloreda jako projektanta připomíná plán Prahy, který byl zveřejněn ve známém spisu Topographia Bohemiae, Moraviae et Silesiae, který vydal Matthäus Merian v roce 1650 ve Frankfurtu nad Mohanem. Před Vyšehradem je zde vybudována rohová hradba v dnešní půdorysné podobě. Hlavním účelem bylo chránit karlovskou bránu Špičku. Bylo s ní počítáno jako s aktivním článkem obrany. Hradby byly v převážně středověké podobě. Dva bastiony jsou nakresleny nad Nuselským údolím a při severním nároží půdorysu. Další byl přiložen k staršímu obvodu na straně k Podolí. 
Není známo, do jaké míry se hr. Conti účastnil zpracování detailních plánů. V roce 1655 byla vsunuta mezi bastiony rohové hradby Táborská brána ještě v pozdně renesančním stylu. Ve stejném roce byl založen skutečně mohutný čtyřkřrídlý objekt vyšehradské zbrojnice $(90 \times 36 \mathrm{~m})$. Její stavbu řídili Johann de Capauli, Carlo Lurago a Santini de Bossi (Kašička-Nechvátal 1975, 109-115). K roku 1656 uvádí A. Romaňák (1964, 1977, 263-280) zásah plukovníka Josefa Priamiho de Rovereto, který byl pověřen stavební inspekcí a navrhl řadu korektur již rozestavěného systému. Celkovou představu konečné podoby vyšehradské citadely naznačil J. Priami již na plánu z roku 1653. Je dobře znám ve své ryté pohledové podobě, kterou zveřejnil o 10 let později Frà Konstantin. Vyšehradská raně barokní zbrojnice byla nevýrazná čtyřkřídlá stavba s protáhlým vnitřním dvorem. Autorem kamenické výzdoby byl Giovanni Babtista Allio, který také pracoval na sochařské výzdobě Leopoldovy brány. Stavba v poslední etapě svého funkčního života, před požárem v roce 1927, sloužila jako poštovní garáže. Demolice stavby byla na základě ofertního řízení svěřena firmě B. Balada, která celou stavbu před zbořením zaměřila. Stavba nebyla podsklepena. Archeologický výzkum Komise pro výzkum Vyšehradu v letech 1924-1935 patrně vždy nepronikl až k terénu podloží. Rozhodnutí císaře Ferdinanda III. z roku 1653 o vybudování pražské pevnosti, s nímž souvisí Priamiho návrh Vyšehradské citadely, znamenalo definitivní zánik středověkého Vyšehradu jako celku. Následovalo vystěhování posledního zbytku obyvatel, kteří přežili válečné období předchozích let a rekatolizační politiku vyšehradské kapituly. Berní rula z roku 1654 uvádí, že Horní město nemá již žádné obyvatele a zbývajících 22 osob žilo tehdy u Botiče v Podvyšehradí. Záhy v roce 1653 byla zahájena další likvidace starší vyšehradské zástavby, která pokračovala i následujícího roku. Zachovaný soupis zbouraných domů, uložený v kapitulním archivu (NA Praha, Archiv kapituly vyšehradské, kart. 99), uvádí řadu měšt’anských domů a dalších objektů zaniklého předbarokního půdorysu, který byl nesporně středověkého původu.

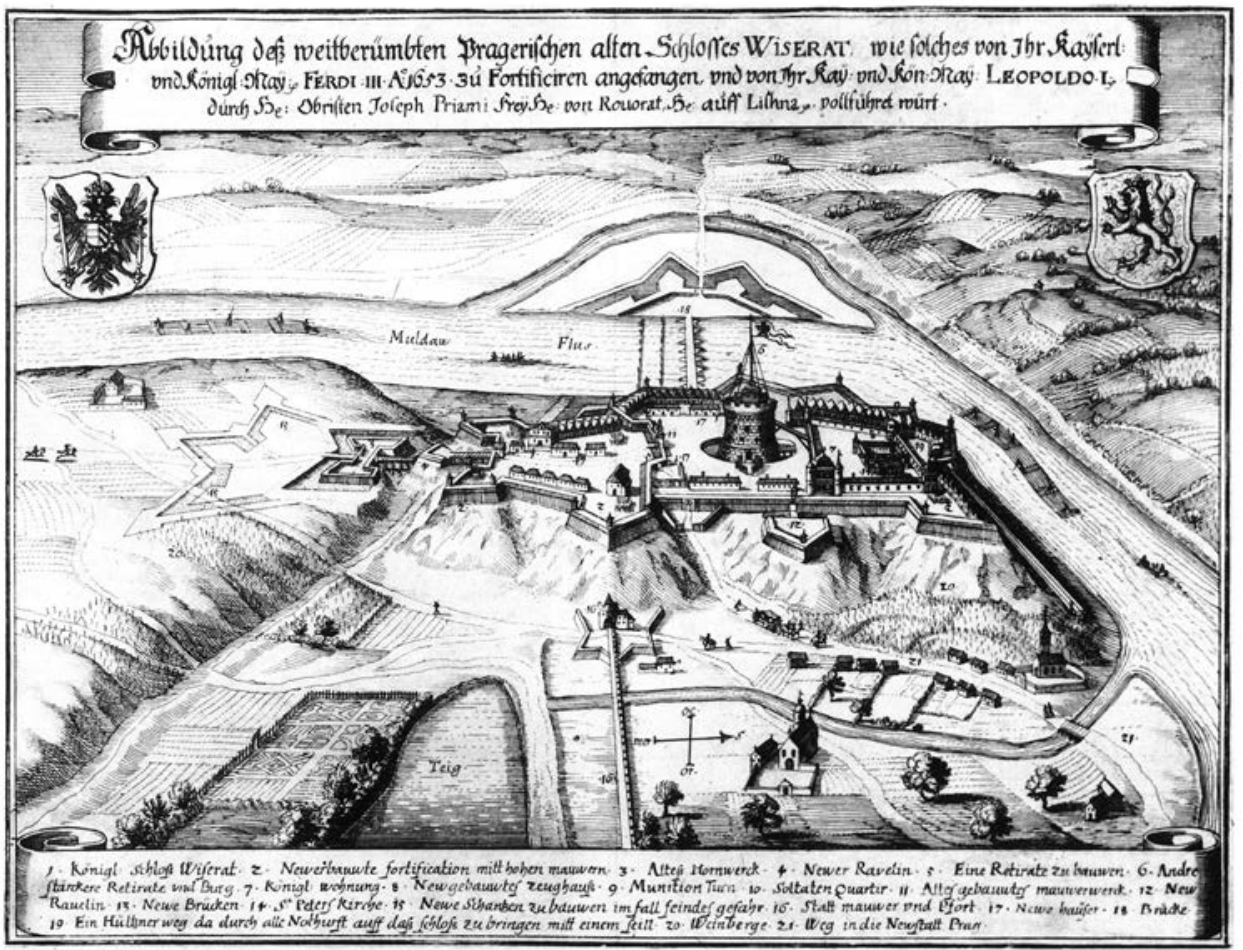

Obr. 1. Praha 2 - Vyšehrad. Návrh Josefa Priamiho na přestavbu vyšehradské pevnosti z roku 1653.

Abb. 1. Prag 2 - Vyšehrad. Entwurf von Josef Priami für den Umbau der Festung Vyšehrad aus dem Jahr 1653. 
Kromě kapitulního soupisu zbořených domů přináší cenné doklady k vyšehradské místopisné topografii historiograf kapituly kanovník Jan Florian Hammerschmidt (1652-1737) ve své dosud cenné práci Prodromus Gloriae Pragensae, etc. (1723, 366-370), která uvádí, že při stavbě fortifikace bylo zničeno celkem 62 domů. Fortifikační práce na Vyšehradě postupovaly zpočátku velmi rychle kupředu a patrně se neměly původně omezit pouze na obvod vlastní hory.

Do roku 1678, kdy řídil opevňovací práce Johann de Capauli, získalo obvodové opevnění vyšehradské pevnosti dnešní podobu s rohovou hradbou, navazovala na torzo gotické hradby po obou stranách bývalé brány Špičky z doby Karla IV., s třemi bastiony proti západu a širokým bastionem sv. Ludmily, který chránil od jihu bývalý okrsek knížecí a královské akropole. Zachované části gotické hradby z doby Karla IV. na severní a jižní straně u brány Špičky již nemají cimbuř́i ani zachovaná torza hradebních věží. Další části gotické hradby jsou zachovány ve značně změněné podobě na jižní straně akropole u baziliky sv. Vavřince. Novodobé restaurační práce z let 2007-2009 značně změnily charakter i strukturu zdiva. Zůstává nedokončen bastion sv. Leopolda proti Podvyšehradí a hradba nad vltavským břehem. Stavební situaci v letech 1680-1685 zachycuje ve značně zkreslené a idealizované podobě mědirytina Folperta van Ouden-Allena. Jsou na ní domyšleny některé rozestavěné úseky a všechny bastiony opatřené sypanými valovými násypy, o nichž bezpečně víme, že nebyly dokončeny ani o století později, jak spolehlivě dokládají některé detaily. Především na severní straně z panoramatu Josefa Daniela Hubra z roku 1769. Zde nemohly v té době existovat ani kasematy u pozdější Cihelné brány, které jsou dílem až pozdější doby. Mědirytina F. Ouden-Allena z let 1680-1685 přináší schéma katastrálních parcel kanovnických zahrad, z nichž některé mohou být i z doby předhusitské, a poměrně značné množství zřícenin ve stř̌ední části Vyšehradu.

V časovém období po roce 1678, kdy byly zhotoveny účtovací plány, se stavební činnost poměrně zvolnila (NA Praha, SM-F 110/3/4). Ještě na Linckově plánu Vyšehradu z roku 1739 je Leopoldův bastion označen jako nedokončený a ravelin nad Podvyšehradím před dnešní Cihelnou bránou se objevuje až na plánech, které zachycují fortifikační práce v době francouzské okupace v roce 1742 pod vedením generála ing. de Berdiquiera (NPÚ, Generální ředitelství Praha, Sbírka plánů, stavebněhistorických průzkumů a restaurátorských zpráv, Vácslav Babička, PPOP-996-5-316).

Součástí projektu J. Priamiho z roku 1653 bylo také rozdělení vyšehradské pevnosti př́íčnou hradbou na dva díly. Měla oddělovat severozápadní část - královský zámek, muniční věž, kasárna a další nové objekty. Priami však především navrhl novou dominantu citadely - mohutnou válcovou věž, oddělenou vlastním příkopem - jako poslední útočiště obránců. Severozápadní část měla obsahovat královské rezidenční sídlo a konkurovat dominantám Pražského hradu. Podle E. Herolda měl být donjon určitou napodobeninou Maxmiliánovy věže v Norimberku (Herold 1894, 112). Rovněž je také poukazováno na př́ibuznost s věží Theresianum v Salcburku. Nelze se také zcela vyhnout určitému porovnání s Andělským hradem v Římě, který mohl být i prvotní inspirací autora projektu. Celé Nuselské údolí měla na severovýchodní straně překračovat stará gotická karlovská hradba, do jejíhož těla se měla vsadit pevnůstka s branou, a celek měl být chráněn velkým rybníkem.

I když je vývoj opevnění Vyšehradu tématem poměrně početné literatury (Wirth 1948; Romaňák 1964; 1977; 1986; Romaňák-Picková 1966; Kašička-Nechvátal 1983; Kupka 1996; Bat'ková et al. 1998; Vlček 1998; Kupka et al. 2002; Durdík 2008; Nechvátal 2012), zůstává mnohé $\mathrm{v}$ detailu nedostatečně poznáno, zvláště vzhledem k likvidaci nejen středověkého opevnění, ale především městečka Hory Vyšehradu, které bylo svým původem ještě z předhusitského období.

Úmrtím Karla VI. (20. 10. 1740) vymřela habsburská dynastie v mužské linii po meči. Mnoho dosud neznámého přináší následující období v době války o tzv. dědictví habsburské (1741-1748). Vlády v dědičných zemích Habsburků se ujala na základě pragmatické sankce dcera Karla VI. Marie Terezie (1740-1780). Její sňatek s Františkem Lotrinským dal základ habsbursko-lotrinské dynastii, která vládla v našich zemích až do roku 1918. Panovnice musela hájit trůn proti zemím, především Prusku, Bavorsku a Francii, které neuznaly její dědické nároky. Byly to především dvě války o Slezsko (1740-1742 a 1744-1748), které skončily jeho definitivní ztrátou pro českou korunu. Koncem roku (16.-26. 11. 1741) oblehla spojená francouzská, saská a bavorská vojska 


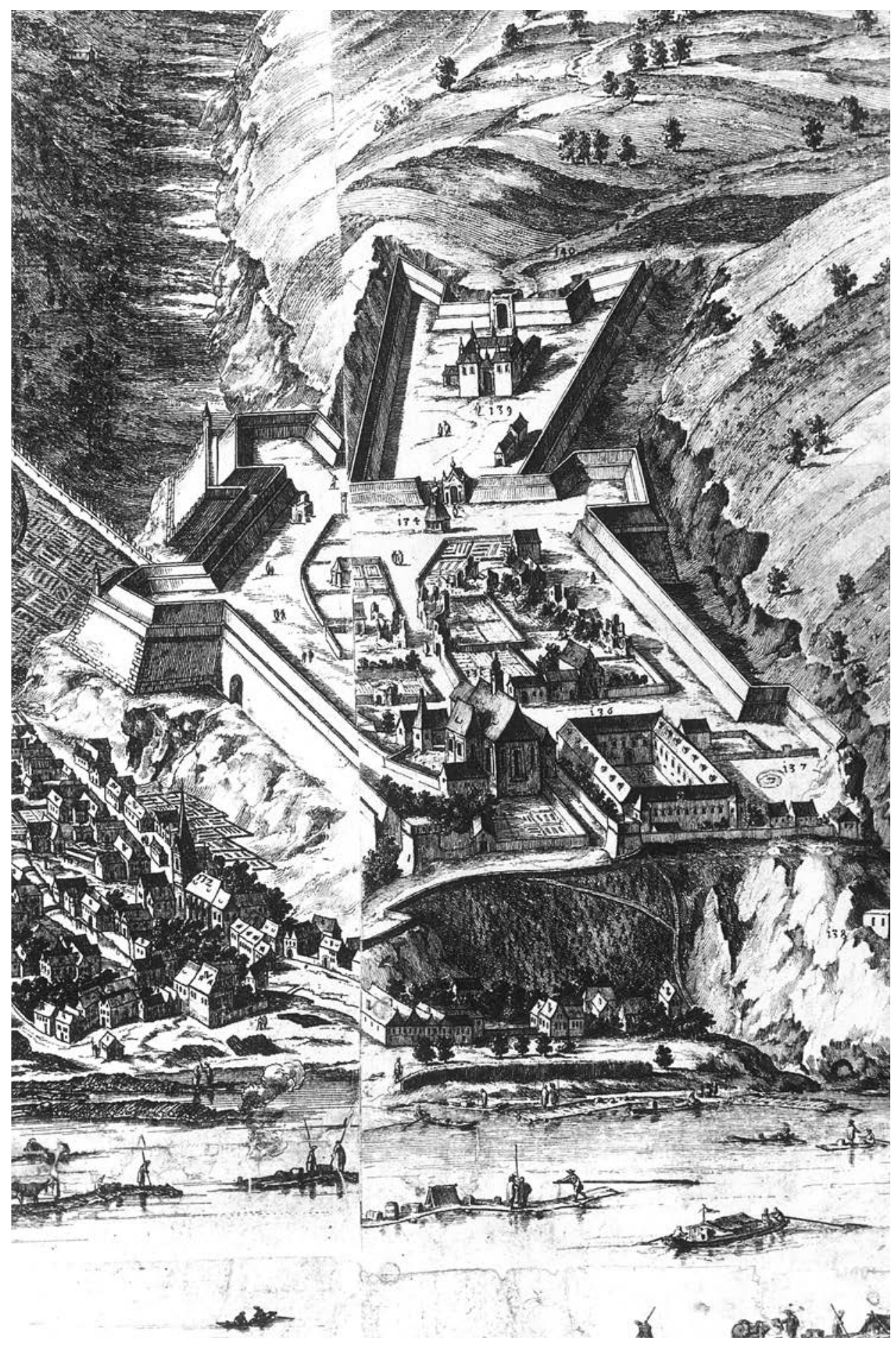

Obr. 2. Praha 2 - Vyšehrad. Vyšehrad na výřezu z panoramatu Folperta van Ouden-Allena z roku 1685.

Abb. 2. Prag 2 - Vyšehrad. Vyšehrad in einem Ausschnitt aus einem Panorama von Folpert van Ouden-Allen aus dem Jahr 1685. 
postupně Prahu. Koncem listopadu (24. 11.) vyzval bavorský kurfiřt Karel Albrecht pražská města, aby kapitulovala. V noci na 26. 11. spojená vojska Prahu dobyla. Město bylo postupně včetně Vyšehradu zatíženo vysokými rekvizicemi a kontribucemi. Počátkem prosince (7. 12. 1741) se nechal bavorský kurfiřt Karel Albrecht prohlásit českým králem. Holdovala mu větší část české šlechty a také církevní hierarchie. Ale záhy 28. 12. 1741 Prahu opouští natrvalo. Již v polovině roku 1742 (2. 7.) bylo na zámečku v Komořanech jednáno s Francouzi o vyklizení Prahy, ale bez úspěchu. V druhé polovině roku 1742 (5. 8. - 8. 9.) rakouské vojsko pod hlavním vedením Františka I. Lotrinského, švagra Marie Terezie, oblehlo bezúspěšně Prahu, která byla okupována Francouzi. Obléhání bylo záhy přerušeno, aby bylo v západních Čechách zastaveno tažení francouzských jednotek na pomoc pražské francouzské posádce. Koncem roku rakouská vojska znovu oblehla Prahu. Sedmnáctého proince 1742 hlavní jádro francouzské posádky opustilo Prahu, ale již 26. 12. podal kapitulaci zbytek. Definitivně opustili Francouzi Prahu 2. 1. 1743.

Vnitřní dějiny Vyšehradu v tomto období zatím nejlépe zachytil kanovník a později první vlastenecký probošt Vojtěch Ruffer (1790-1870) ve své práci Historie Vyšehradská (1861), která nejenže sleduje základní fakta historického vývoje, ale doplňuje je i cennými detaily. Vyšehradská citadela byla až do roku 1741 sídlem skutečně malé posádky. Vojenský velitel Prahy Hermann hrabě Ogilvy zjistil špatný stav pražského opevnění, pouze Vyšehrad byl ve výrazně lepším stavu a měl se stát hlavním bodem obrany Prahy. Ogilvy měl k dispozici na obranu Prahy pouhých 7000 mužů. K Praze směřovala vojska saského kurfiřta, bavorského kurfiřta a francouzského krále, i když odmítl ještě 24. listopadu kapitulaci. Hned ráno a v odpoledních hodinách 26. listopadu 1741 pronikly do Prahy spojené armády a Ogilvy se stal válečným zajatcem. Nové vlády se v Praze ujali francouzští maršálové Francois-Marie vévoda de Broglie a Charles

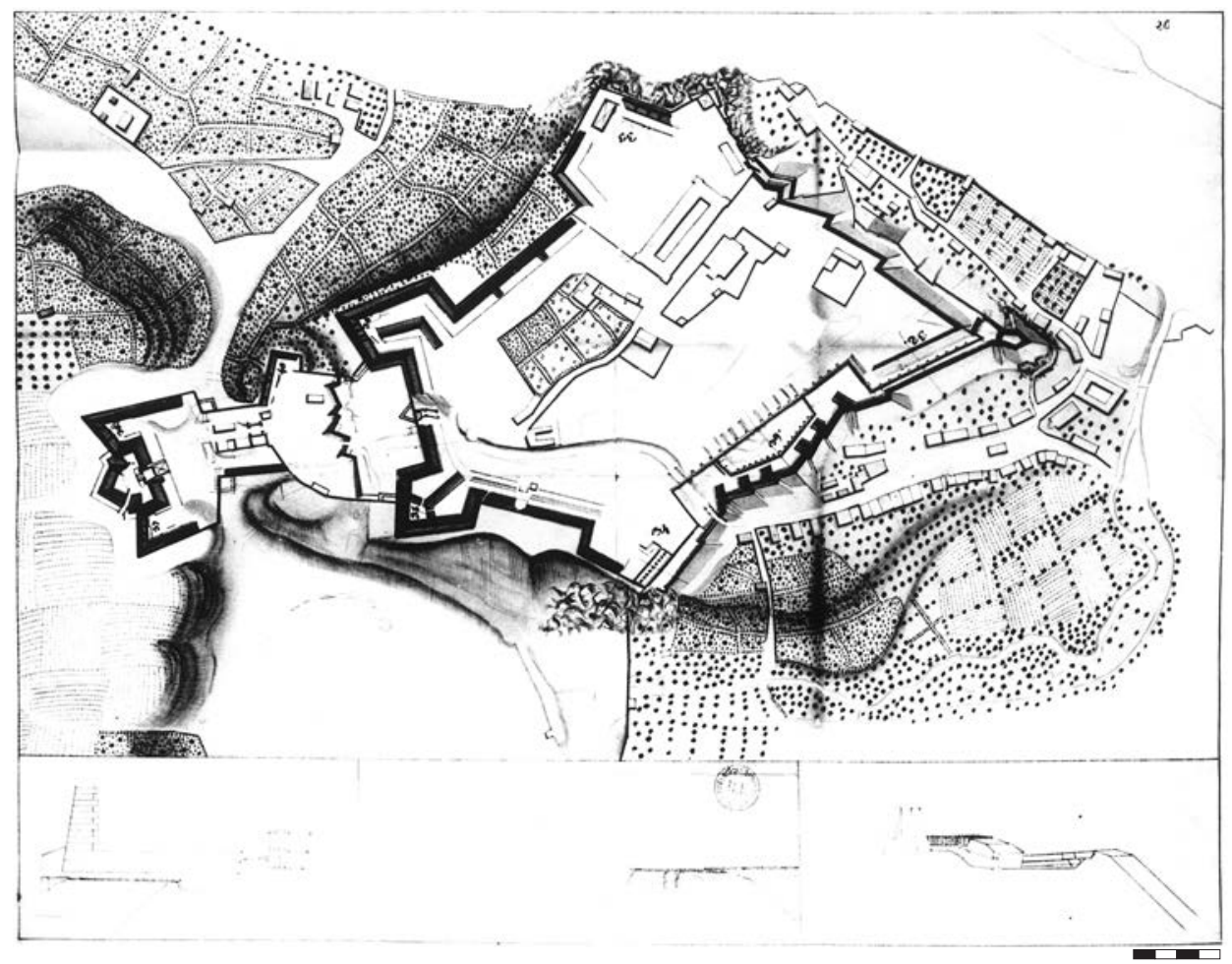

Obr. 3. Praha 2 - Vyšehrad. „Plán citadely v Praze, zvané Vyšehrad, a částí jeho projektu.“ Bibliothéque Nationale, Service photographigue, Paris, Departement des manuscrits, Divers 9984.

Abb. 3. Prag 2 - Vyšehrad. „Plan der Zitadelle in Prag, genannt Vyšehrad, und Teile seines Bauprojekts.“ Bibliothéque Nationale, Service photographigue, Paris, Departement des manuscrits, Divers 9984. 
Louis August Fouquet de Belleisle. Při dobytí Prahy netřeskl na Vyšehradě ani jeden výstřel. Vyšehradká posádka se vzdala bez boje, Ogilvy nařídil vojákům, aby složili zbraně.

Francouzská správa města vyhlásila nové kontribuce a začala zabavovat obyvatelům v té době obleženého města i potraviny. Hned od počátku okupace Prahy a především Vyšehradu začali francouzští ženijní inženýři vylepšovat obranné bastiony a připravovali i zaplavení novoměstského př́kopu Botičem. Tradičně se v odborné literatuře uvažuje, že v této době byl i dokončen systém kasematů, což neodpovídá skutečnosti. Ještě na ortografickém nárysu Prahy od J. D. Hubra z roku 1769 je celá část bastionů na severní straně odkrytá a jsou vidět početné opěrné pilíře. Tytéž částečně zasypané opěrné pilíře jsou v těchto místech na obraze Vincence Morstadta z roku 1833 v pohledu na Táborskou bránu od rotundy sv. Martina (Kašička-Nechvátal 1985, obr. 80).

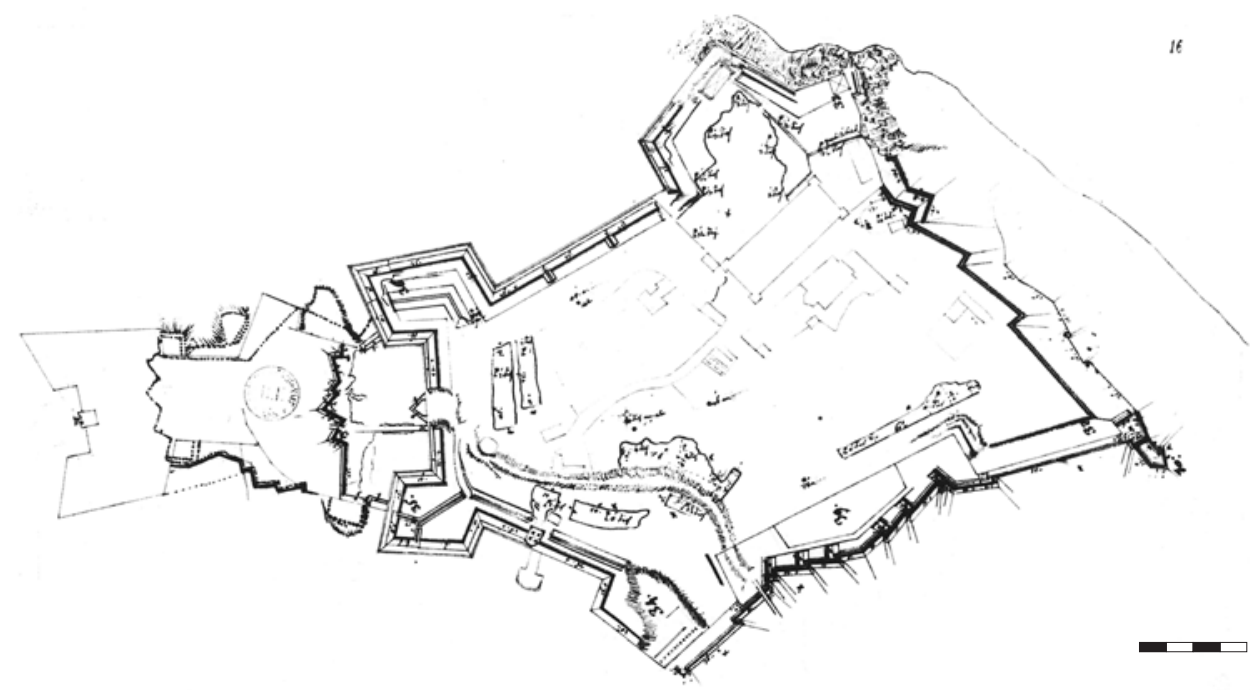

Obr. 4. Praha 2 - Vyšehrad. Plán vyšehradského opevnění s okolními pozemky, zahradami a vinicemi.

Abb. 4. Prag 2 - Vyšehrad. Plan der Befestigung des Vyšehrad mit benachbarten Grundstücken, Gärten und Weinbergen.

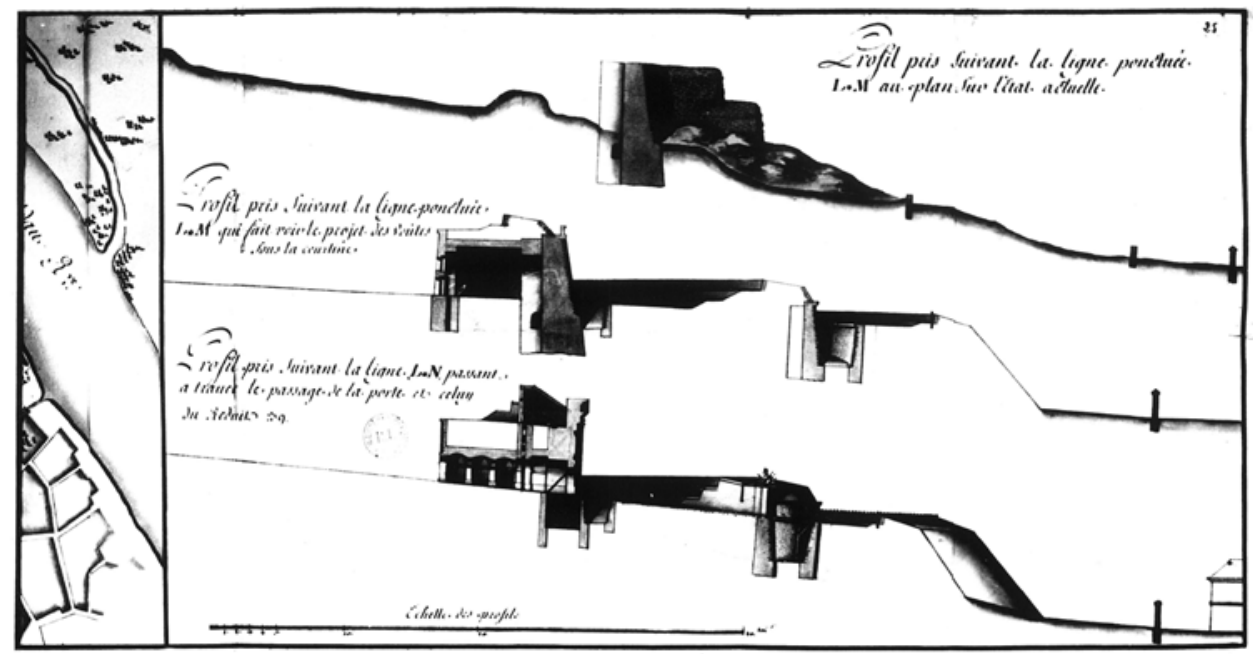

Obr. 5. Praha 2 - Vyšehrad. Profily území podle linie L-M a L-N (s branou) na plánu podle nynějšího stavu.

Abb. 5. Prag 2 - Vyšehrad. Geländeprofile gemäß Linien L-M und L-N (mit Tor) auf dem Plan nach dem jetzigen Zustand. 


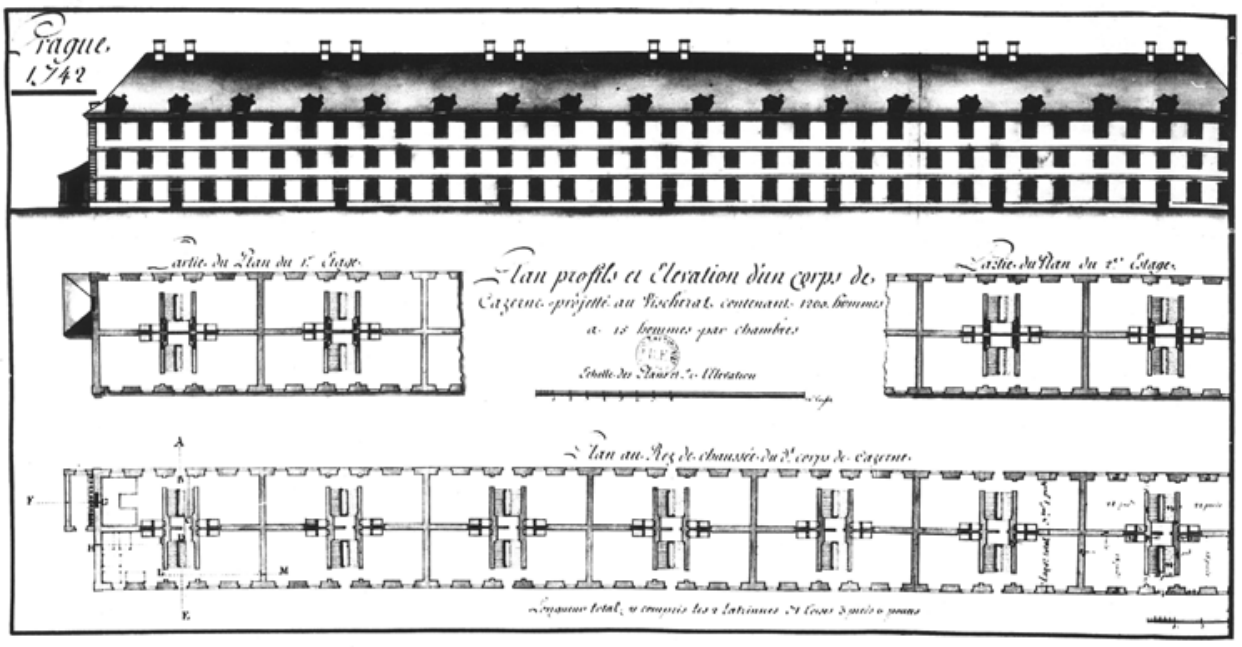

Obr. 6. Praha 2 - Vyšehrad. Praha 1742. Kasárny. Projekt kasáren na Vyšehradě, určených pro 1260 mužů, po 15 mužích v každé místnosti.

Abb. 6. Prag 2 - Vyšehrad. Prag 1742. Kasernen. Entwurf der Kasernen auf dem Vyšehrad, bestimmt für 1260 Mann, jeweils 15 Mann in jedem Raum.

Až do období letních měsíců 1742 vládli Praze Francouzi. V době uzavření míru mezi Rakouskem a Pruskem ve Vratislavi se stává jejich situace již kritická. Byli vzdáleni od svých armád a také značně od francouzských hranic. Když začal švagr Marie Terezie Karel Lotrinský obléhat Prahu, odřízl Francouzům přístupové cesty. Francouzi chtěli hájit Prahu, dokud je nevysvobodí francouzská armáda (Janáček 1964, 249-252).

V záŕí 1742 se začala situace měnit. Karel Lotrinský obléhání přerušil a vytáhl vstříc francouzským jednotkám maršála Mailleboise, který obsadil Cheb a chystal se k dalšímu útoku na Prahu. Francouzské plány se rozpadly a obléhání Prahy pokračovalo pod vedením rakouského císařského generála Kristiána z Lobkovic. Francouzská vojska pod vedením Belleisle - Brogglie mezitím odjel z Prahy - se pokusila probít do Chebu. Již v polovině prosince 1742 (16. prosince) Francouzi opustili Prahu. Ve městě zůstalo pouze 1800 vojáků a 4000 nemocných pod vedením podplukovníka Françoise de Cheverta. Hájení Prahy bylo nemožné. Za několik dnů dává Chevert rozkaz, aby se vojáci stáhli na Hrad a Vyšehrad. Již 26. prosince začíná jednání o čestné kapitulaci. Záhy, již 28. prosince, odchází francouzská posádka z Vyšehradu. Bez jediného výstřelu ho obsadili císařští. Počátkem roku (2. ledna 1743) Chevertova vojska odešla z Prahy, nechala zde pouze nemocné jako válečné zajatce.

Zmíněný historiograf Vyšehradské kapituly V. Ruffer ve svých dějinách uvádí z tohoto období dvě zprávy regionální povahy. První z nich uvádí, že bylo nařízeno kapitulnímu děkanovi, „aby kázal dělati jámy na zahradě u Botiče pro ostatky pobitých koní, nebot' již koňské maso lid jísti musil“" (Ruffer 1861, 358). Koňské maso bylo ve středověku, ale i v pozdějším období určitou pojistkou proti vyhladovění pro obležené (Beranová 2005, 74). Druhá zpráva zmiňuje pece na pečení chleba: „Francouzové na Vyšehradě pece měli na pečení chleba, a sice tu, kde nyní bývalá strážnice u hřbitova stojí. Teprve roku 1834 poslední památka oněch pecí rozkopána byla; byly tu tři pece vedle sebe“ (Ruffer 1861, 358). Obě zprávy jsou cenné svou konkrétností, i když je nelze v detailu komentovat. K tomuto období francouzské okupace Vyšehradu (1742) má také zprávu známá sběratelka pověstí a spisovatelka Popelka Biliánová (1862-1941), když vypráví o francouzském majorovi, který byl údajně na Vyšehradě při bojích zabit a strašil noční chodce.

Soubor plánů Vyšehradu z tohoto období je uložen v Národní knihovně v Paříži s četnými doplňky, z nichž některé jsou skutečně na hranici fantazie. Plány byly zjištěny př́i archivním průzkumu bohemik dr. Vácslavem Babičkou, kterému vděčím za upozornění. Vojenský inženýr a architekt du Portal se účastnil vojenského tažení do Čech v letech 1741-1742 a nakreslil při 


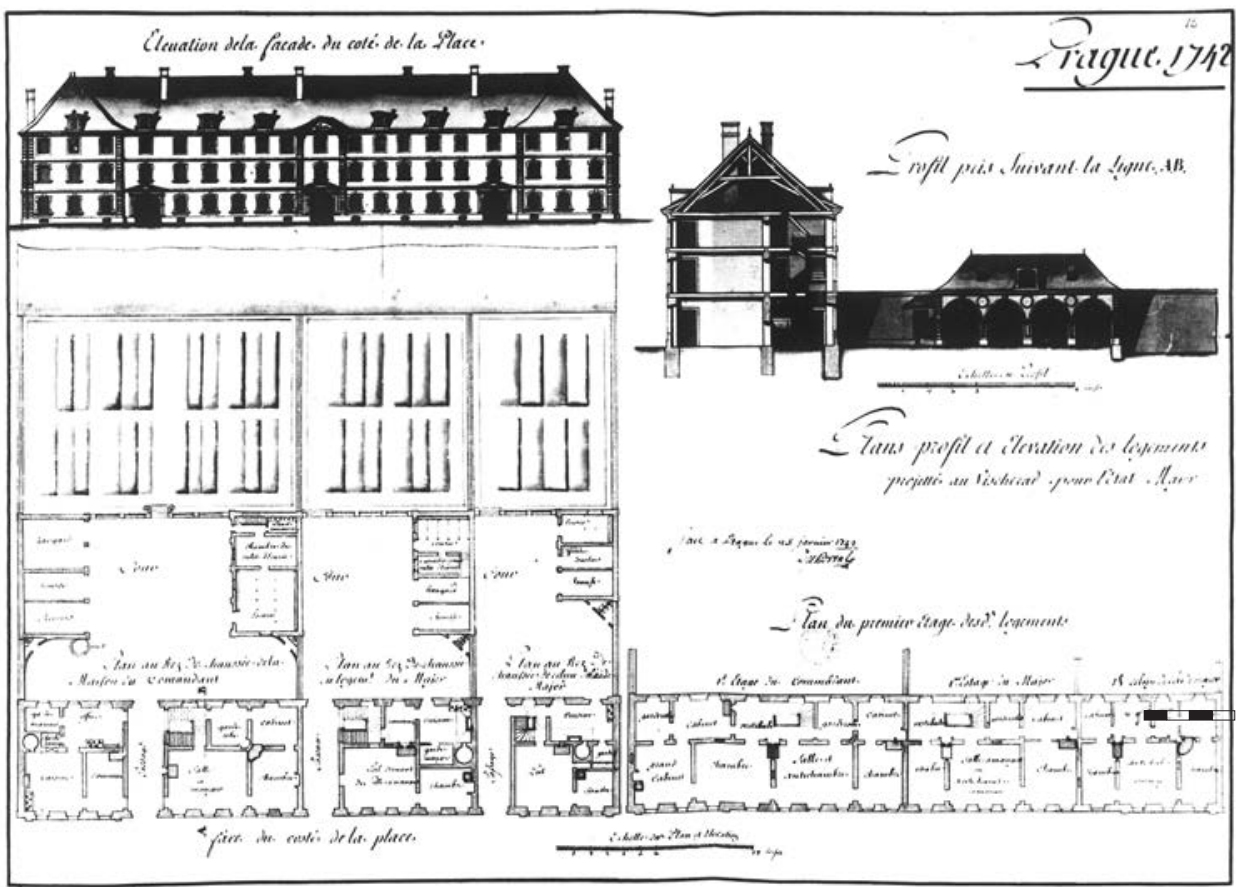

Obr. 7. Praha 2 - Vyšehrad. Praha 1742. Projekt obytného domu pro velitele a dva majory.

Abb. 7. Prag 2 - Vyšehrad. Prag 1742. Entwurf eines Wohnhauses für Kommandanten und zwei Majore.

něm plány Chebu, Boru u Tachova, Plzně, Berouna a Prahy. Atlas plánů Vyšehradu je uložen v oddělení rukopisů ve fondu Nouvelles acquisitions françaises, pod číslem 23049 a pod názvem Papiers du Portal XXXVIII-XXXIX, Bohême, etc. Díky pochopení ředitele AÚ ČSAV doc. PhDr. M. Richtra, DrSc., byly získány v roce 1980 nejen pozitivy, ale také negativy celého souboru.

V době francouzské okupace Prahy v roce 1741, a především v roce 1742 byly na Vyšehradě pod vedením generála ing. Berdiquiera prováděny rozsáhlé úpravy k vylepšení obranného systému. Došlo k částečné výstavbě kasematů především na východní straně, jak je patrno na

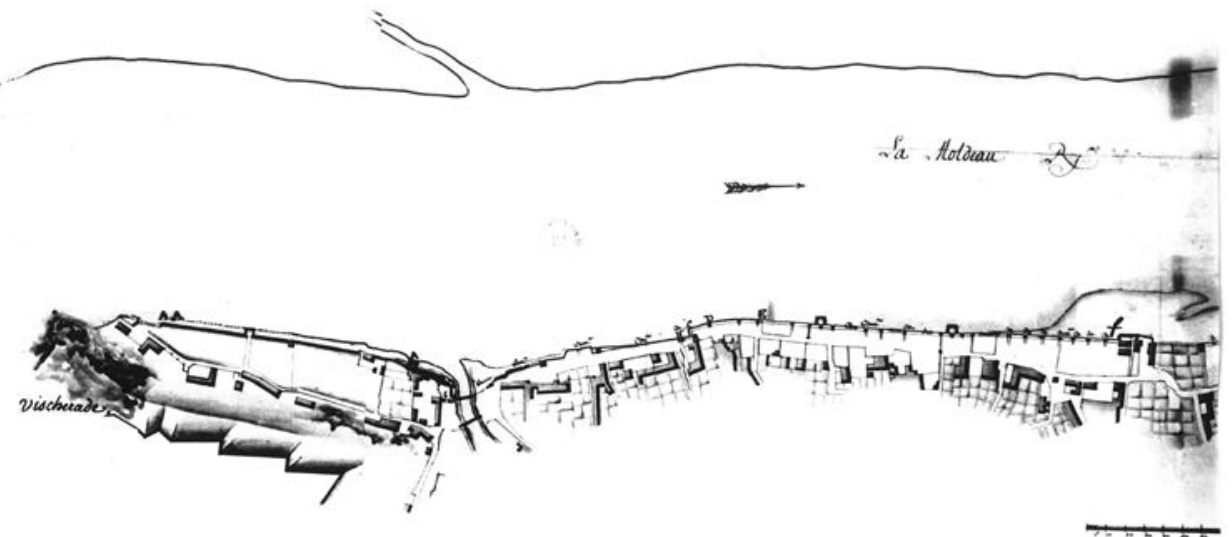

Obr. 8. Praha 2 - Vyšehrad. Řeka Vltava. Vyšehrad, pobřeží s body A, A, A, C, D, E, F (Podvyšehradí prvá část). Abb. 8. Prag 2 - Vyšehrad. Fluss Moldau. Vyšehrad, Ufer mit den Punkten A, A, A, C, D, E, F (nördliche Vorburg erster Teil). 


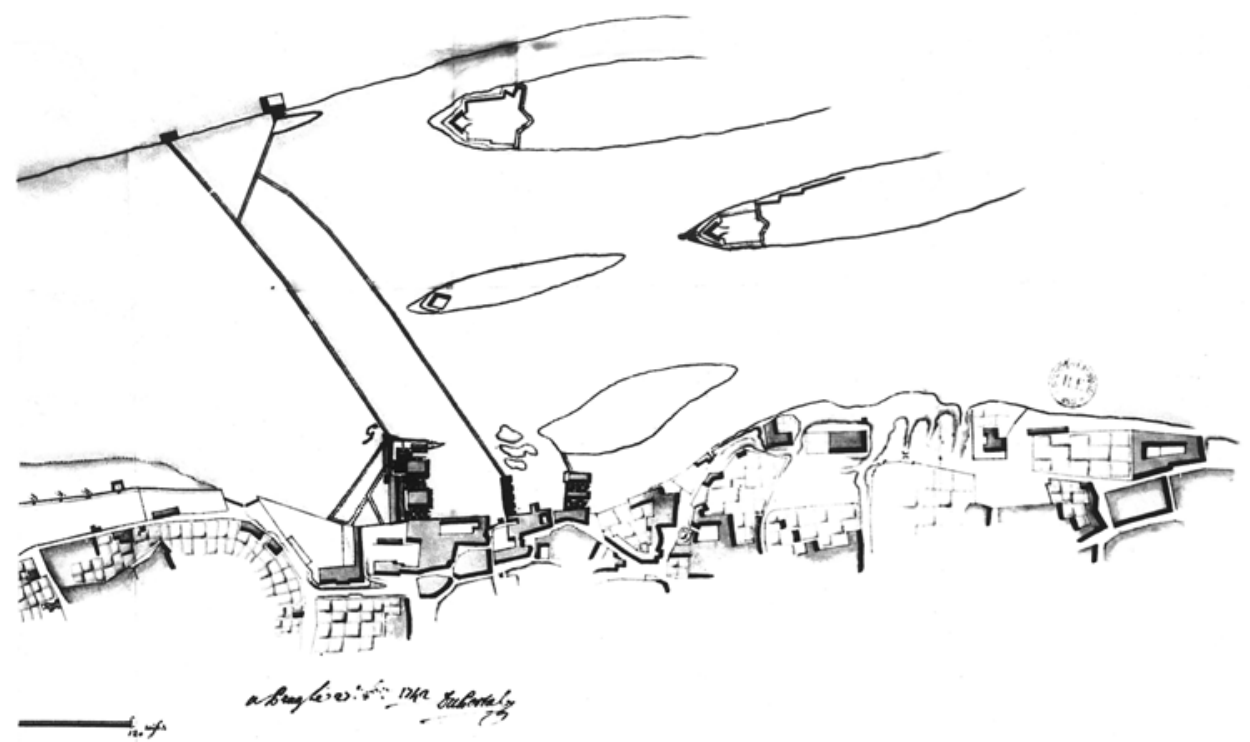

Obr. 9. Praha 2 - Vyšehrad. Pokračování obr. 8. V Praze 27. října 1742 du Portal. Řeka Vltava s ostrovy, jezem a mlýny. Abb. 9. Prag 2 - Vyšehrad. Fortsetzung von Abb. 8. Prag, am 27. Oktober 1742 du Portal. Fluss Moldau mit Inseln, Wehr und Mühlen.

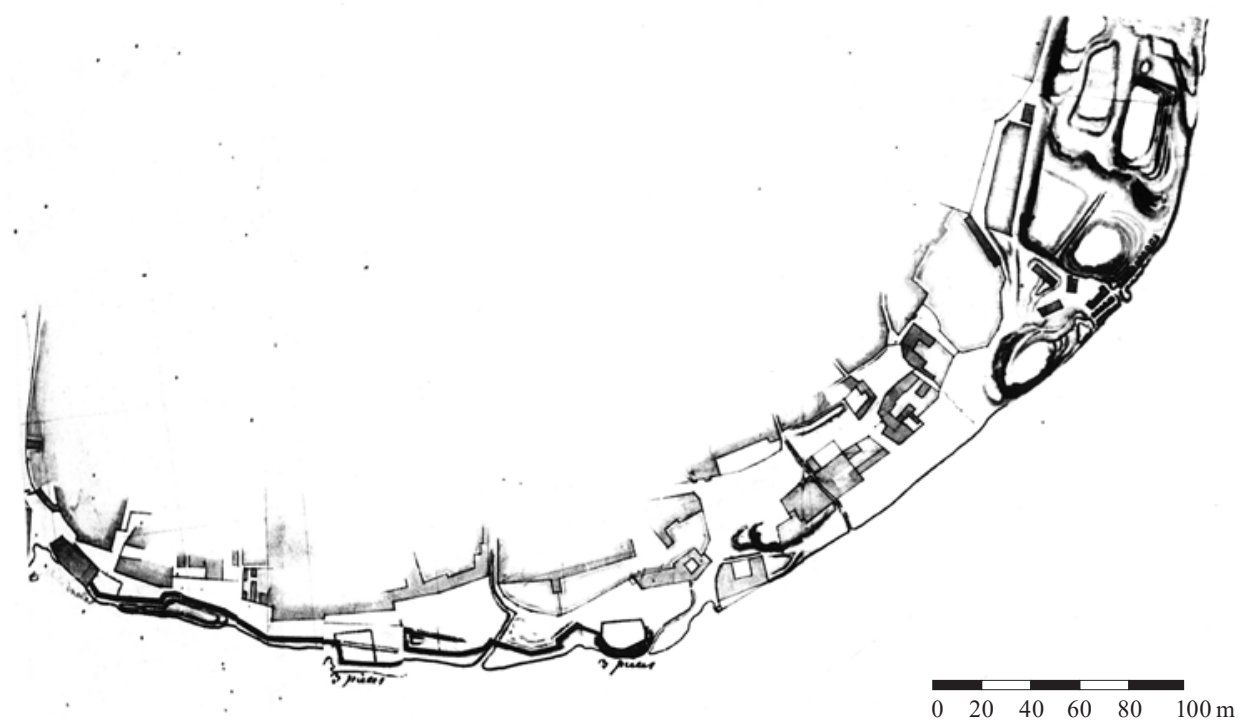

Obr. 10. Praha 2 - Vyšehrad. Mapa pobřeží - úsek od Rejdiště po východní okraj Starého Města.

Abb. 10. Prag 2 - Vyšehrad. Karte des Ufers - Abschnitt zwischen der Renngasse (Na Rejdišti) und dem Ostrand der Altstadt.

rozsáhlé části násypů, i když jejich počátky byly patrně v dřivější době. Byly také zvýšeny násypy s palisádami při Leopoldově bráně, přičemž byl na ni dočasně osazen francouzský znak stavebníka. Po odchodu Francouzů byl odstraněn; jeho podobu neznáme. V tomto období byl také realizován i ravelin nad Podvyšehradím před dnešní Cihelnou bránou, s nímž počítaly již plány po třicetileté válce. 


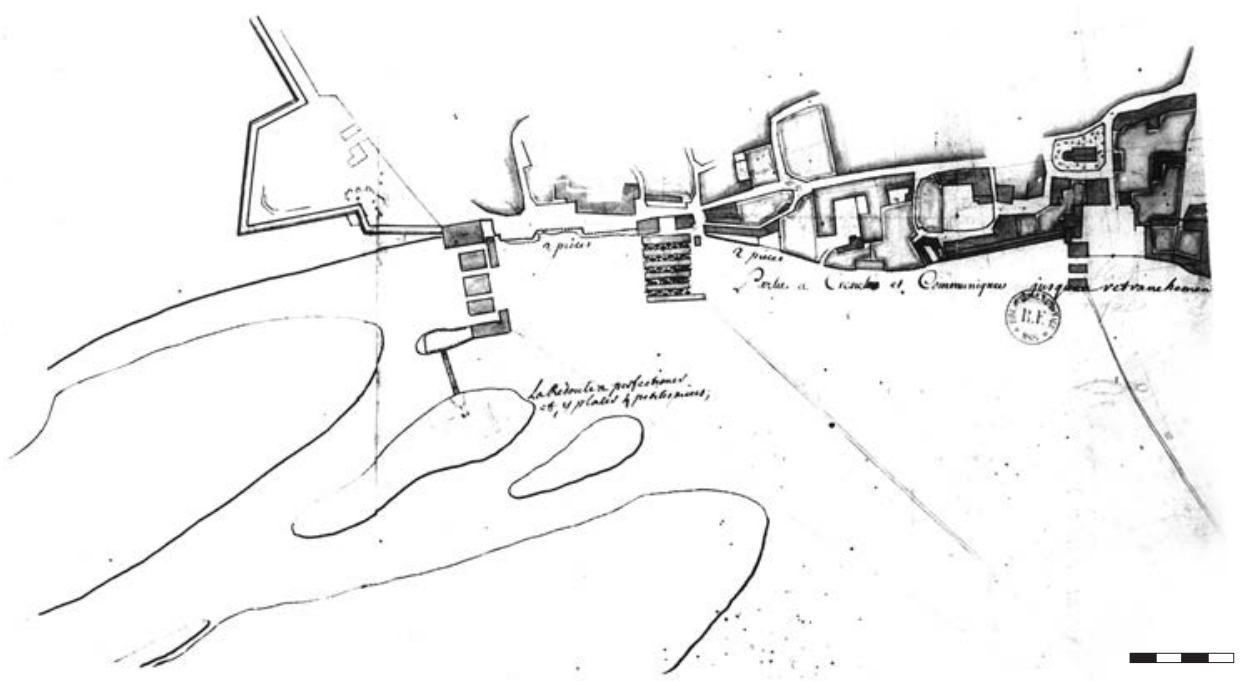

Obr. 11. Praha 2 - Vyšehrad. Mapa pobřeží na dolním Novém Městě. Abb. 11. Prag 2 - Vyšehrad. Karte des Ufers an der unteren Neustadt.

Skutečně velký rozsah stavebních francouzských prací zaznamenává „Plán královského zámku Vyšehradu s nově založenými francouzskými hradbami“ z této doby (Nechvátal 2012, 266, obr. 34). Z plánu je patrno, že Francouzům šlo především o obranu pevnosti Vyšehradu proti městu. Celý obvod hradby nad Podvyšehradím od staré gotické karlovské zdi přes Nuselské údolí až po bastion sv. Leopolda, včetně nového ravelinu, zabezpečili dvojitou krytou cestou s dvěma řadami palisád. Nároží bastionu zesílila malá reduta. Dalšími novými palisádami byla hájena poprsní hradba od bastionu sv. Leopolda k prachárně v obvodu bývalé královské akropole, kterou sledovalo druhé palisádování. Bylo v místech, kde se dalo na horu vystoupit. K ovládání řeky pod Vyšehradem osadili Francouzi palisády podél celého pobřeží. Byla zde snad napodobena starší situace ze 17. století. Před Táborskou branou bylo navršeno vnější opevnění. Další krytá cesta s palisádami přetínala předhradí před příkopem proti Leopoldově bráně, $\mathrm{k}$ získání ústupové cesty, kdyby se nepřítel zmocnil předhradí. Ve vlastní pevnosti se počaly budovat kasematy určené nejen $\mathrm{k}$ bezpečnému přesunu vojska, ale také $\mathrm{k}$ ubytování posádky. V bastionech byla postavena zemní tělesa, tzv. traverzy, které měly chránit proti boční palbě.

Atlas vojenského inženýra du Portal obsahuje mezi jinými plány Vyšehradu, jak vypadal při prríchodu francouzského vojska, plány opevnění a ubytování vojska, plán opevnění proti Novému Městu a proti Vltavě, projekt přístavby citadely a kasáren pro 1260 mužů, plány důstojnického pavilonu, muničních skladišt' a dalších objektů. Se zvláštní pozorností je třeba uvést půdorysné plány pravého břehu Vltavy téměř až k dnešnímu Palackého pomníku a vlastně starému Podskalí (po dolní Nové Město), včetně ostrovů na Vltavě a jejich opevnění. I když zde bude nutné revizní srovnání, jelikož některé části zaměření vyjadřují určitou schematizaci. Soubor plánů atlasu du Portala (celkem 30 plánů) jednoznačně svědčí o tom - stejně jako ikonografické prameny ze 17. a 18. století -, že v úseku vlastní plošiny hradiště na jižní straně v oblasti kanovnických zahrad a na severní straně v oblasti Karlachových sadů nedošlo k poškození terénu při fortifikačních pracích. Jsou zde zachovány stratigrafie v původním stavu, jak svědčí kromě jiného i nález tzv. trikonchy byzantské architektury (Varadzin-Nechvátal 2012; v tisku) datované do období Boleslava II. (972-999) do konce 10. století z roku 2014. Jsou zde zachovány terény v původním stavu a možnosti archeologického výzkumu na řadu desetiletí.

Pokud není v popiscích uvedeno jinak, jde o plány Vyšehradu uložené v Národní knihovně v Paříži. 


\section{Prameny a literatura}

BAŤKOVÁ, R. et al., 1998: Umělecké památky Prahy. Nové Město, Vyšehrad, Vinohrady. Praha. BERANOVÁ, M., 2005: Jídlo a pití v pravěku a středověku. Praha.

Bibliothéque Nationale, Paris, Departement des manuscrits, fond Nouvelles acquisitions françaises, n. 23 049, Papiers du Portal XXXVIII-XXXIX, Bohême.

Československé dějiny v datech. Praha 1987.

Dějiny Prahy v datech (Míka, Z., ed.). Praha 1988.

Dějiny zemí Koruny české v datech (Čapka, F., ed.). Praha 1999.

DURDÍK, T., 2008: Vyšehrad Fortress in Prague, Europa Nostra Scientific Bulletin 62, 119-124.

HAMMERSCHMIDT, J. F., 1723: Gloria et Majestas sacro-sanctae, regiae exemptae et nulius diaecesis, Wissehradensis ecclesiae ss. apostolorum Petri et Pauli. Pragae.

HEROLD, E., 1894: Vyšehrad - Malebné cesty po Praze I. Praha.

JANÁČEK, J., 1964: Vyprávění o Vyšehradu. Praha.

KAŠIČKA, F.-NECHVÁTAL, B., 1975: Barokní zbrojnice na Vyšehradě, ZPP 35, 109-115.

- 1983: K počátkům barokní citadely na Vyšehradě, Staletá Praha XIII, 191-202.

- 1985: Vyšehrad pohledem věků. Praha.

KUPKA, V., 1986: Pevnost Praha. Praha.

KUPKA, V. et al., 2002: Pevnosti a opevnění v Čechách, na Moravě a ve Slezsku. Praha.

NECHVÁTAL, B., 2012: Od středověkého opevnění Vyšehradu k raně barokní citadele - Zur mittelalterlichen Befestigung Vyšehrad. In: Královský Vyšehrad IV (Nechvátal, B., ed.), 219-283. Praha.

ROMAŇÁK, A., 1964: Obranný systém pražskej bastionovej fortifikácie, Historie a vojenství 3, 939-981.

- 1977: Př́íspěvek k dějinám stavebního vývoje Vyšehradu, Památky a příroda 1, 263-281.

- 1986: Příspěvek k dějinám pražské fortifikace. In: Documenta Pragensia VI/1, 201-235. Praha.

ROMAŇÁK, A.-PICKOVÁ. V., 1966: Z dejín novodobého pevnostného stavitelstva, Historie a vojenství 5 , 1061-1090.

RUFFER, V., 1861: Historie vyšehradská neb vypravování o hradu, kapitule a městu hory Vyšehradu u Prahy v Království českém. Praha.

VARADZIN, L.-NECHVÁTAL, B., 2012: Nové poznatky o předrománském kostele centrální dispozice na Vyšehradě (Předběžná zpráva), PRP XIX, 170-176.

- v tisku: An Unexpected Pre-Romanesque Architecture at Prague-Vyšehrad, Czech Republic, Byzantinoslavica.

VLČEK, P., 1998: Opevnění Vyšehradu. In: Bat'ková, R. et al., Umělecké památky Prahy. Nové Město, Vyšehrad, Vinohrady, 735-740. Praha.

WIRTH, Z., 1948: Zmizelá Praha 5. Opevnění Prahy, Vltava v Praze, Ztráty na památkách 1939-1945. Praha.

ZEMAN, J., 2011: Kasematy na Vyšehradě a také jinde. Rukopis.

\section{Zusammenfassung}

\section{Die Pläne des Vyšehrad in der Pariser Nationalbibliothek}

Die ersten Pläne und Arbeiten zur Verbesserung der noch im 14. Jahrhundert unter Karl IV. errichteten Schanzen des Vyšehrad tauchten bald nach der Schlacht am Weißen Berg auf. Das tatsächlich größte Unheil für die Schanzen des Vyšehrad brachte das Ende des Dreißigjährigen Kriegs selbst mit sich, als die Schweden im Jahr 1648 in Prag einfielen. Die von Kaiser Ferdinand III. im Jahr 1653 getroffene Entscheidung, die Prager Festung auszubauen, womit der Entwurf der Zitadelle von Josef Priami zusammenhing, bedeutete einen endgültigen Untergang des mittelalterlichen Vyšehrad als Ganzes. Es folgte die Aussiedlung der letzten Bewohner, welche die Kriegszeit der vorhergehenden Jahre überlebt hatten, und eine Rekatholisierungspolitik des Vyšehrader Kapitels. Bis zum Jahr 1678, als die Befestigungsarbeiten von Johann de Capauli geleitet worden waren, erhielt die Außenbefestigung der Vyšehrader Festung die heutige Gestalt mit einer Eckschanze und schloss an beiden Seiten des ehemaligen, aus der Zeit Karls IV. stammenden Spitzen Tores mit drei nach Westen gerichteten Basteien und der breiten Ludmilla-Bastei, die den einstigen Fürstenbezirk und die königliche Akropolis von Süden her schützte, an den gotischen Schanzentorso an. 
Die Bautätigkeit hat sich in der Zeit nach 1678, als die Abrechnungspläne erstellt wurden, deutlich verlangsamt (Nationalarchiv Prag, SM-F 110/3/4). Noch auf Lincks Plan des Vyšehrad aus dem Jahr 1739 wird die Leopoldbastei als nicht fertiggestellt bezeichnet, und der Ravelin oberhalb der nördlichen Vorburg vor dem heutigen Chotek-Tor taucht erst auf Plänen auf, welche die Befestigungsarbeiten zur Zeit der französischen Okkupation im Jahr 1742 unter der Leitung des Generals und Ingenieurs de Berdiquier dargestellt werden (Nationales Denkmalinstitut, Generaldierektion Prag, Plänearchiv, PPOP-996-5-323).

Während des sogenannten Österreichischen Erbfolgekriegs (1741-1748) wurde Prag und der Vyšehrad vor allem von der französischen Armee belagert (1741-1742). Eine Kollektion von Plänen des Vyšehrad aus jener Zeit wird in der Pariser Nationalbibliothek aufbewahrt und enthält zahlreiche Ergänzungen, von denen einige tatsächlich bis zur Grenze der Phantasie reichen. Die Pläne wurden im Rahmen der von dem Bohemisten Dr. V. Babička durchgeführten Archivforschungen entdeckt, dem wir für den Hinweis dankbar sind. Der Kriegsingenieur und Architekt du Portal nahm in den Jahren 1741-1742 am Kriegszug nach Böhmen teil und zeichnete dabei Pläne von Eger, Bor bei Tachov, Pilsen, Beroun und Prag. Ein Atlas der Pläne wird in der Handschriftenabteilung unter der Nummer 23049 im Bestand Nouvelles acquisitions françaises unter der Bezeichung Papiers du Portal XXXVIII-XXXIX, Bohême, etc. aufbewahrt. Dank dem Verständnis des Direktors des Archäologischen Instituts der Akademie der Wissenschaften der Tschechischen Republik, Herrn Doz. PhDr. M. Richter, DrSc., konnten nicht nur die Positive, sondern auch die Negative der ganze Kollektion der Vyšehrader Pläne (insgesamt 30 Stück) erworben werden.

Während der französischen Okkupation von Prag wurden im Jahr 1741 und vor allem im Jahr 1742 auf dem Vyšehrad unter der Leitung von General de Berdiquier umfangreiche Umbauten zur Verbesserung des Verteidigungssystems durchgeführt. Dabei kam es zu einer teilweisen Errichtung der Kasematten, dies vor allem an der Ostseite, wie an den ausgedehnten Aufschüttungen zu erkennen ist, obwohl ihre Anfänge offenbar in früherer Zeit lagen. Auch die Aufschüttungen mit den Palisaden am Leopold-Tor wurden höher gelegt, wobei auf ihnen vorübergehend das französische Wappen des Bauherrn angebracht war. Nach dem Weggang der Franzosen wurde es entfernt; sein Aussehen ist uns heute unbekannt. In dieser Zeit wurde auch der Ravelin oberhalb der nördlichen Vorburg vor dem heutigen Chotek-Tor errichtet, der bereits auf den Plänen nach dem Dreißigjährigen Krieg eingzeichnet war.

Der wirklich große Umfang der französischen Bauarbeiten wird auf einem aus jener Zeit stammenden „Plan des Königsschlosses Vyšehrad mit neu angelegten französischen Wehrmauern" festgehalten (Nechvátal 2012, 266, Abb. 34).

Aus dem Plan ist ersichtlich, dass es den Franzosen vor allem um die Verteidigung der Festung Vyšehrad gegen die Stadt ging. Die ganzen Außenwehrmauern oberhalb der nördlichen Vorburg ab den alten gotischen Mauern aus der Zeit Karls IV. durch das Nusle-Tal bis zur Leopoldbastei einschließlich des neuen Ravelins wurden durch einen doppelt überdachten Weg mit zwei Palisadenreihen gesichert. Die Eckbastei wurde durch eine kleine Redoute verstärkt. Mit weiteren neuen Palisaden wurde die Brustwehr ab der Leopoldbastei bis zum Pulvermagazin im Bereich der ehemaligen Königsakropolis verteidigt, worauf eine zweite Palisadensetzung folgte. Diese befand sich an den Stellen, an welchen man auf den Burgwall hochsteigen konnte. Um den Fluss unterhalb des Vyšehrad zu kontrollieren, setzten die Franzosen Palisaden am ganzen Ufer entlang. Dort hat man wohl die ältere Situation aus dem 17. Jahrhundert kopiert. Vor dem Tabor-Tor wurde die Außenbefestigung entworfen. Ein weiterer überdachter Weg mit Palisaden teilte die Vorburg vor dem Graben gegenüber dem Leopold-Tor, um einen Rückzugsweg zu gewinnen, falls der Feind die Vorburg erobern sollte. In der Festung selbst machte man mit dem Bau von Kasematten weiter, die nicht nur für ein sicheres Vorrücken der Soldaten, sondern auch zur Unterbringung der Truppen bestimmt waren. In den Basteien wurden Erdkörper, sog. Traversen errichtet, die gegen einen Beschuss von der Seite her Schutz bieten sollten.

Der Atlas des Kriegsingenieurs du Portal enthält unter anderem Pläne des Vyšehrad, wie er bei der Ankunft der französischen Armee ausgesehen hatte, Pläne der Befestigung und der 
Unterbringung der Armee, ein Plan der Befestigung in Richtung Neustadt und der Moldau, ein Umbauprojekt für den Anbau einer Zitadelle und von Kasernen für 1260 Mann, Pläne für einen Offizierspavillon, ein Munitionslager und für weitere Objekte. Mit besonderem Augenmerk müssen die Grundrisspläne des rechten Moldauufers bis fast zum heutigen Palacký-Denkmal und eigentlichen alten Siedlung Podskalí einschließlich der Moldauinseln aufgeführt werden. Obgleich hier ein Revisionsvergleich nötig sein wird, da einige Teile bezüglich der Maße eine gewisse Schematisierung aufweisen. Die Kollektion der im Atlas von du Portal enthaltenen Pläne (insgesamt 30 Pläne) bezeigt - ebenso wie die ikonoggraphischen Quellen aus dem 17. und 18. Jahrhundert - eindeutig, dass es in dem Abschnitt des eigentlichen Burgwallplateaus an der Südseite im Bereich der Gärten der Dekanei und an der Nordseite im Bereich der Karlach-Gärten bei den Befestigungsarbeiten zu keiner Beschädigung des Geländes gekommen war. Die Schichtenfolgen sind dort im ursprünglichen Zustand erhalten geblieben, wie unter anderem auch durch den im Jahr 2014 gemachten Fund der in die Zeit Boleslav II. (972-999) in das Ende des 10. Jahrhunderts datierten byzantinischen Dreikonchenarchitektur angedeutet wird (Varadzin-Nechvátal 2012; im Druck). Die Gelände sind dort im ursprünglichen, unveränderten Zustand erhalten und bieten somit für einige Jahrzehnte die Möglichkeit für archäologische Grabungen.

Falls nicht anders angegeben handelt sich um Pläne des Vyšehrad, die in der Pariser Nationalbibliothek aufbewahrt werden.

PhDr. Bořivoj Nechvátal, CSc., Archeologický ústav AV ČR, Praha, v. v. i., výzkum Vyšehrad, Štulcova 4, 12000 Praha, Česká republika, tel. 224918 758,nechvatal@arup.cas.cz 